\title{
ORIENTATION OF BIOLOGICAL PROCESSES IN THE ROOT ZONE OF POTATO PLANTS UNDER THE INFLUENCE OF FERTILIZERS AND BIOLOGICAL PREPARATION
}

\author{
V. V. Volkohon ${ }^{1}$, M. A. Zhurba ${ }^{1}$, S. B. Dimova ${ }^{1}$, L. M. Tokmakova ${ }^{1}$, \\ K. I. Volkohon ${ }^{1}$, O. I. Protsenko \\ ${ }^{2}$ Chernihiv branch of State Institution «Soil Protection Institute of Ukraine» \\ 41, Malynovskoho Str., Chernihiv, 14020, Ukraine
}

The existing systems of crops fertilization typically do not account for the environmental protection requirements, as required doses of fertilizers are calculated by the nutrients removal rates (NPK) with planned yield, and the degree of use of fertilizers active ingredient is rather low. Thus, according to the averaged data the rates of nitrogen fixation are within 0.35-0.50, phosphorus - not more than $0.2 \%$, potassium $-0.25-0.60$ depending on soil type. [1] The methods for calculating the required amount of fertilizers would be ideal if fertilizer absorption were at the rate of $100 \%$. Since it is impossible, the use of such calculations leads to deliberate pollution with unused fertilizers. In this regard special concern is about mineral nitrogen as the biggest polluter of agrocenoses.

Theoretically, nitrogen fertilizers should be applied within the physiological relevance. Only under this condition we can minimize the risk of pollution with dangerous to human life nitrogen compounds. But the criterion of truth - what amount of mineral nitrogen can be considered physiologically appropriate for plants - is unknown. Such opportunity appeared with the development of biological testing methods, including the use of indicators of functional activity of nitrogen fixation bacteria associated with the roots of crops. Since nitrogen fixers are able to fix nitrogen from the atmosphere only in the absence of excessive amounts of nitrogen compounds in the environment, and as they are closely connected with the roots of plants, by the determination of nitrogenase activity of the bacteria of the root zone of plants grown in different agricultural backgrounds, we can take choose such a dose that will not reduce the activity of the process compared to the control (without nitrogen) variant. On the other hand, we know that diazotrophs stop fixing nitrogen from the atmosphere in case of nitrogen fertilizers excess and start using its bound forms, since it is energetically more favourable for bacteria cells. Thus, in addition to nitrogen fixation for constructive metabolism, bacteria carry out denitrification process. So, having followed $\mathrm{N}_{2} \mathrm{O}$ emission activity at different doses of mineral nitrogen we can select the one that does not cause significant losses of gaseous nitrogen from the soil. Comparing the peculiarities of the process of nitrogen fixation and denitrification in agrocenoses, we can select optimal dose of mineral nitrogen in physiological aspect [2].

An additional test for the feasibility of crops fertilization is the determination of the intensity of mineralization processes in agrocenoses soils, incl. the indicators of carbon dioxide emission.

In connection with the above, the goal of the study was to determine the orientation of biological processes in the root zone of potato plants under the effect of different fertilization systems.

Materials and methods. The study was conducted during 2011-2013 in stationary field experiments on leached black soil $\left(\mathrm{pH}_{\text {sal }}\right.$. 5.2 ; humus content $-3.01 \%$, easily hydrolized nitrogen - $109 \mathrm{mg} / \mathrm{kg}$, mobile forms of phosphate $\left(\mathrm{P}_{2} \mathrm{O}_{5}\right)-168 \mathrm{mg} / \mathrm{kg}$, exchangeable potassium $\left(\mathrm{K}_{2} \mathrm{O}\right)-58 \mathrm{mg} / \mathrm{kg}$ of soil $)$ of the Institute of Agricultural Microbiology and Agroindustrial Manufacture of NAAS. Potato of Bellaroza variety was grown in rotation: potato - spring barley - pea - winter wheat. We determined the feasibility of such fertilization systems: organic, low mineral, medium mineral, high mineral and organicmineral.

Under organic system of fertilization in crop rotation the manure was applied at the rate of $40 \mathrm{t} / \mathrm{ha}$ once per rotation during 
autumn ploughing (for potato). Mineral fertilization of potato involved the use of $\mathrm{N}_{40} \mathrm{P}_{40} \mathrm{~K}_{40}, \quad \mathrm{~N}_{80} \mathrm{P}_{80} \mathrm{~K}_{80}$ and $\mathrm{Na}_{120} \mathrm{P}_{120} \mathrm{~K}_{120}$. Organo-mineral system included the application of $40 \mathrm{t} / \mathrm{ha}$ of manure and mineral fertilizers $\left(\mathrm{N}_{80} \mathrm{P}_{80} \mathrm{~K}_{80}\right)$.

The experiment scheme also included a block of variants, where microbial preparation Biogran (TU 24.1-00497360-006: 2009) was used at the aforementioned agricultural backgrounds.

The area of experimental plot -86.4 $\mathrm{m}^{2}(7.2 \times 12.0 \mathrm{~m})$, the repetition of the experiment is quadruple. The location of plots is randomized.

The potential activity of nitrogen fixation of potato plants in rhizosphere soil was determined by M. Umarov [3]. To evaluate the emission of nitrogen oxide in the system "soil-plant" the method of closed chambers was used [4;5]. The 10 litres chambers with rubber membrane for gases separation were punched into the soil to the depth of $10 \mathrm{~cm}$, the soil around the chambers was humidified to create a water gate. Weighing bottles with calcium carbide moistened with water to produce acetylene, which inhibits nitric oxide reductase and constrains the process of $\mathrm{NO}_{3}^{-} \mathrm{NO}_{2}^{-}$ dissimilation on at the stage of nitric oxide restoration, were placed into the chambers to determine $\mathrm{N}_{2} \mathrm{O}$ emission intensity. The exposure was performed for three hours after which gas samples were taken and placed into previously evacuated vessels. The repetition of sampling is three-time.

The selected gas samples were analyzed by gas chromatograph. Nitrogenase activity was determined by gas chromatograph "Chrom-4" with a flame ionization detector (steel column of $3 \mathrm{~m}$ length filled with sorbent Parapak Q 60-80 mesh; thermostat temperature $40^{\circ} \mathrm{C}$, gas flow: hydrogen - $15 \mathrm{~cm}^{3} / \mathrm{min}$., nitrogen - 10 $\mathrm{cm}^{3} / \mathrm{min}$., and air $-500 \mathrm{~cm}^{3} / \mathrm{min}$.).

Direct $\mathrm{N}_{2} \mathrm{O}$ emission was measured by gas chromatograph "Tsvet $500 \mathrm{M}$ " with the detector of electrons capture. Columns temperature $-40^{\circ} \mathrm{C}$, evaporator temperature $120^{\circ} \mathrm{C}$, detector $-330^{\circ} \mathrm{C}$. The losses of carrier gas (argon with methane 95/5) - $35 \mathrm{~cm} 3 / \mathrm{min}$. Sorption steel column $3 \mathrm{~m}$ high filled with sorbent Parapak Q 60-80 mesh.

$\mathrm{CO}_{2}$ concentration was measured by gas chromatograph "Tsvet 500 M" with thermal conductivity detector (bridge current $130 \mathrm{~mA}$ ). Temperature of columns $25^{\circ} \mathrm{C}$, detector $-40^{\circ} \mathrm{C}$. The losses of carrier gas (helium) $-20 \mathrm{~cm}^{3} / \mathrm{min}$. [3]. Sorption steel columns were filled with sorbent Parapak Q 60-80 mesh.

The experiment performance, crop record and statistical analysis of the results were carried out by B. Dospiekhov [6]. The content of starch, nitrates and ascorbic acid were determined according to the methods [7].

Thus, according to the obtained results, the lowest dose of mineral fertilizers is optimal for environmental positions, but the compromise between environmental feasibility and culture performance suggests in favour of promising choice of $\mathrm{N}_{80} \mathrm{P}_{80} \mathrm{~K}_{80}$. It makes sense (though with some reservations) to apply $40 \mathrm{t} / \mathrm{ha}$ of manure under potato.

To optimize the ecological state of agrocenoses, to increase potato productivity and to improve products quality the use of microbial preparation Biogran is promising in the technologies of growing crops. 